\title{
Welfare to work: time for a rethink
}

\author{
Steve Fothergill* \\ CRESR, Sheffield Hallam University
}

\begin{abstract}
Labour's welfare to work policies had merit in a strong labour market but are undermined by a weak demand for labour in the post-recession world. Progress was anyway limited in bringing down the numbers on incapacity benefits, and in older industrial Britain in particular, where so many of these claimants are concentrated, there is a pressing need to rethink welfare reform.
\end{abstract}

Keywords: Unemployment, Welfare reform, Incapacity benefits.

Since 1997 the assumption underpinning just about all Labour's welfare reforms has been that if claimants look for work, and equip themselves for work, they should be able to find work. This assumption was always rather questionable in some parts of the country, and in the wake of recession now looks distinctly outmoded. The time has arrived for a rethink.

During the long economic boom in the decade and a half up to 2008, Labour's approach to bringing down benefit numbers was not without merit. The growing economy was generating more jobs - more than two million of them - so there was a clear need to make sure that benefit claimants had the skills and motivation to fill emerging vacancies. There was also a need to ensure that moving into work was financially worthwhile, which is where tax credits (and to some extent the minimum wage) fitted into the jigsaw.

The post-1997 achievements were considerable, if uneven. Claimant unemployment - that is, the number out of work on Jobseeker's Allowance (JSA) - fell from around 1.8 million to a trough of around 800,000 just before the recession, and even at 1.6 million in early 2010 remains far below the three million of the early 1980 s and 1990s. Keeping JSA claimants in touch with the labour market and providing support to the longer-term claimants through the New Deals can probably claim some of the credit. The numbers on Income Support as a lone parent also dropped to around 700,000, even before more restrictive eligibility was introduced late in 2008.

The achievements in terms of incapacity benefit (IB) numbers have been less impressive. After 1997 the number of working-age IB claimants continued to rise, albeit slowly, reaching a peak in 2003. Thereafter the numbers fell a little, with the biggest reductions in the places where the IB claimant rate had been highest. 
Nevertheless, by 2010, 2.6 million men and women of working age remained out-ofwork on incapacity benefits.

The government probably missed a golden opportunity to bring down IB numbers a lot further during the latter stages of the long economic boom. By comparison with the welfare-to-work initiatives targeted at the claimant unemployed, the initiatives for IB claimants lacked penetration into the potential client group and never really provided the intensive and sustained support, including physical and/or mental rehabilitation, that many IB claimants require in order to re-engage with the labour market. More recent reforms - the national roll-out of the Pathways to Work programme and the introduction of conditionality for new Employment and Support Allowance claimants are moves in the right direction but have come after the prime opportunity has passed.

In the event, a substantial part of the UK job growth that occurred after 2004 was met by rising numbers of migrants, especially from the new EU member states of central and eastern Europe, rather than by a reduction in the numbers on incapacity benefits.

The recession and its aftermath set a new context. It would be a bold commentator who confidently predicted the trends in economic output and employment over the next few years, but it seems reasonable to assume that for some years ahead the relatively strong demand for labour that characterised the years up to 2008 will not return. There is now, without question, a 'demand side' dimension to UK labour market problems in addition to the 'supply side' problems on which post-1997 welfare reforms were predicated.

Even if the economy recovers well, it is to be expected that the unemployed currently on Jobseeker's Allowance will again find work more quickly than incapacity claimants. JSA claimants are more closely in touch with the labour market - indeed, they have to look for work as a condition of benefit receipt. The vast majority have been on benefit for a shorter period, and employers are likely to prefer candidates with recent work experience. Incapacity claimants have not only been on benefit longer half for at least five years - but also tend to be poorly qualified and have mainly lowgrade manual work experience, as well as ill health or disability. ${ }^{1}$

So where does that leave the huge numbers on incapacity benefits? In a very uncomfortable position is probably the answer.

In the short-run the numbers on incapacity benefits are likely to fall, but not because more will be finding work. A new, tougher medical test - the Work Capability Assessment - was introduced for new claimants in late 2008. From October 2010 onwards it will be applied to existing claimants as they are moved across onto the new Employment and Support Allowance. Experience so far with the new test is that large numbers will in future be denied access to incapacity benefits. Some will then be eligible for Jobseeker's Allowance, but others are likely to be pushed out of the benefits system altogether because other sources of household income (such as a partner in work or a pension) means that they will fail to qualify for means-tested JSA.

In the context of recession and its aftermath, pushing ahead with the transfer of existing IB claimants to Employment and Support Allowance, via the Work Capability Assessment, looks like a mistake. Many existing IB claimants will legitimately argue that their poor health, poor skills, extended periods on benefit and (often) advancing years render their chances of finding employment just about nil. That so many of them live in the weaker labour markets of the UK, where district-level IB claimant rates in excess of 10 per cent of all adults of working age are not uncommon, and that there has just been a recession adds to the force of their arguments. The welfare reforms 


\section{p. 5. Welfare to work: time for a rethink}

that are planned to hit existing IB claimants from later in 2010 look set to cause much personal distress and to deliver little in the way of positive outcomes.

The sternest challenge for welfare to work is to be found in those parts of Britain where, even after a decade and a half of economic growth, a large swathe of the workforce remains on incapacity benefits. The high numbers on IB are above all a problem of older industrial Britain - places like the Welsh Valleys, the industrial North East, North West and Yorkshire, and Glasgow and its hinterland in Scotland. In these places a big increase in the numbers on incapacity benefits, among both men and women, was the principal way in which in the long-run labour markets adjusted to job losses in formerly dominant industries like coal, steel and engineering. Sky-high IB claimant rates were never a feature of much of southern England, including London.

In the post-recession world the chances of bringing IB numbers down in older industrial Britain, other than by tougher medical tests, have severely diminished. Nor does the problem simply fade away as a generation of ex-industrial workers made redundant in the 1980 s and 90 s finally reaches state pension age. In practice, where there is an imbalance in the local labour market this group is simply being replaced by a younger generation of disadvantaged and marginalized workers with health problems.

Solving the demand side problems in the labour market, nationally and locally, looks central to any lasting solution. But in the meantime, what should the government do about the vast numbers languishing on incapacity benefits? This is a key challenge for welfare to work policies over the coming years.

Forcing claimants to chase jobs that are few in number and that they are never likely to get is a waste of time. Pushing them off benefits will only accentuate poverty and social disadvantage. But can any government afford either the benefit bill or the colossal waste of productive potential amongst those who might work in the right circumstances and would be willing to return to work? Welfare to work, it seems, needs some radical new thinking.

\section{Notes}

${ }^{1}$ For a full description and analysis of incapacity claimants see in particular Beatty, C., Fothergill, S., Houston, D., Powell, R. and Sissons, P. (2009) Women on Incapacity Benefits, available at www.shu.ac.uk/cresr. This report also includes statistics on male IB claimants.

* Correspondence Address: Steve Fothergill, Centre for Regional Economic and Social Research, Sheffield Hallam University, Howard Street, Sheffield, S1 1WB. Email: natsec@ccc-alliance.org.uk. 